\title{
DEMAND ON FOREIGN ASSETS IS FALLING, BANK CURRENCY ACCOUNTS ARE STABLE ${ }^{1}$ \\ M.Khromov
}

2015 saw a noticeable reduction on the part of economic agents for assets in foreign currency. This signified a decrease in investments in foreign assets both for the population and for organizations (for individuals - savings in foreign exchange cash) with relatively stable (for organizations) and growing (for population) currency accounts in Russian banks.

The Russian residents' demand for assets in foreign currency ${ }^{2}$ has been contracting since 2014. As of 2014 year-end, aggregate increase of these assets constituted $\$ 118 \mathrm{bn}$, including currency assets of individuals went up by $\$ 25 \mathrm{bn}$ and of non-credit organizations - by $\$ 93 \mathrm{bn}$. In 2015, aggregate increase of foreign currency assets amounted to $\$ 43 \mathrm{bn}$, in other words, this indicator shrank by 3 -fold in comparison with the previous year. Assets of legal entities have moved up by $\$ 46 \mathrm{bn}$, which is only half against a year earlier.

In Q1 2016, this trend on the whole remained. Individuals reduced their total foreign currency assets by \$3bn (in Q1 2015 - by \$4bn). Organizations were continuing reducing demand for foreign currency assets to $\$ 14 \mathrm{bn}$ compared to $\$ 23 \mathrm{bn}$ a year earlier.

As a result, by 2016 Q1-end, according to our estimates, demand for foreign currency assets fell to $\$ 36 \mathrm{bn}$ in annual terms (sliding for four quarters). This is even below 2010 indicator when minimum values of the indicator fell to $\$ 43 \mathrm{bn}$. However, now this decrease differs from the one of 2010. Then, the reduction of demand for foreign assets was a reaction to an excessive dollarization registered at the end of 2008-beginning 2009 in the wake of the so called smooth devaluation. Simultaneously, the ruble money supply was growing, which attested to falling dollarization in the Russian economy. However, now the ruble money supply has grown not so significantly. Decrease of the foreign assets is due, to our opinion, to the political instability in relations with foreign partners, general contraction of the dollar volume of the Russian economy owing to significant devaluation of the national currency as well as reduction of income given the deterioration of terms of trade by $14 \%$ of GDP (\$180bn) in 2015.

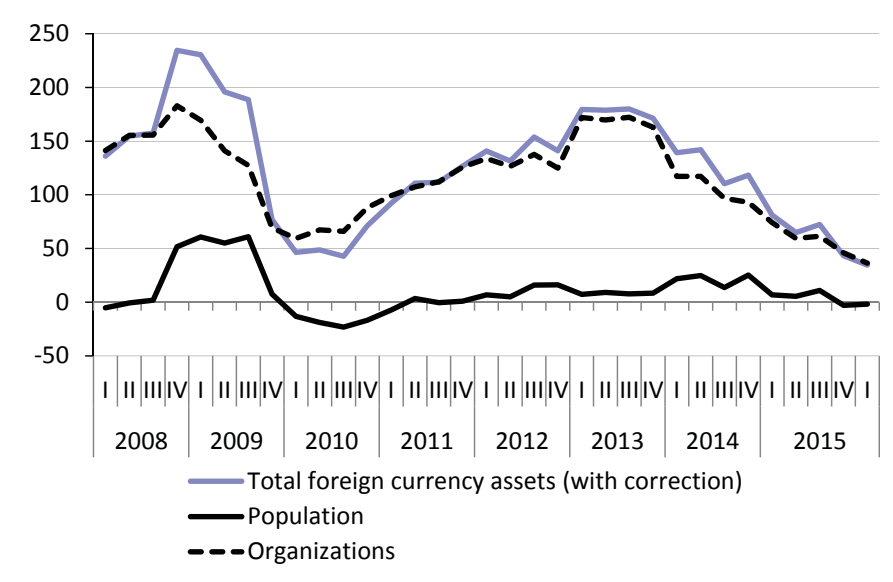

Fig. 1. Demand for foreign currency assets over 4 quarters, USD bn

1 This paper was originally published in Online Monitoring of Russia's Economic Outlook No.7(25).

2 Growth of foreign currency accounts in Russian banks (foreign currency components of broad monetary base) and net increase of foreign assets including operation with foreign currency cash with Russian banks. 
Precisely, contraction of foreign assets has driven the decrease of demand for foreign currency assets. In 2014, foreign assets of non-banking sector (including individuals and Russian non-credit organizations) moved up by $\$ 105 \mathrm{bn}$, which on the whole corresponds to the level of the previous years $(2012-\$ 114 b n$, 2013 minus Rosneft purchase operations of TNK-BP - \$94bn). In 2015, investments in foreign assets fell 5 -fold to $\$ 21 b n$. Dynamics of investments in foreign cash switched to

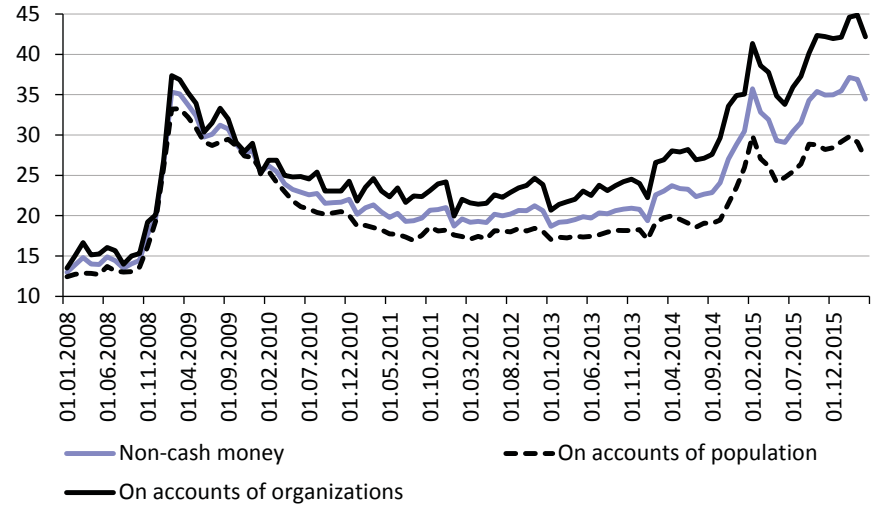

Fig. 2. Share of foreign currency accounts in the total volume of accounts in Russian credit organizations the contrary from increment in the amount of \$30bn in 2014 to decrease by \$10bn in 2015. In Q1 2016, foreign currency reserves have remained practically unchanged. Other foreign assets in 2015 moved up by only \$32bn instead of \$75bn a year earlier. In Q1 2016, reduction of demand for foreign assets continued. Its growth constituted merely $\$ 7 \mathrm{bn}$, which is half the amount a year earlier ( $\$ 15 \mathrm{bn})$.

For the population the year 2015 laid the foundations for selling foreign currency savings. Annual increment of foreign currency accounts (\$7bn) turned out to be lower than contraction of foreign currency savings. At the beginning of 2016, the population additionally reduced foreign currency accounts by around $\$ 3 \mathrm{bn}$. Nevertheless, the share of foreign currency accounts held by individuals so far remains rather high - close to $30 \%$.

Where in case of the population in 2015 - the beginning of 2016, the unload of foreign cash was partially compensated by the growth of foreign currency accounts in Russian banks, then legal entities reduced both investments in foreign assets and in growth of foreign currency accounts in Russian banks from \$18bn in 2014 down to $\$ 14$ bn in 2015. In Q1 2016, this trend continued: the foreign currency accounts of legal entities grew 1.5 time slower than a year earlier - by $\$ 6 \mathrm{bn}$ instead of $\$ 9 \mathrm{bn}$. Meanwhile, the level of dollarization on corporate bank accounts remains at the maximum level since H2 2015, which is both above the peak of early 2009 and late 2014, reaching in March 2016 45\%. It should be noted that the dynamics of foreign currency accounts share in the overall volume of broad money mass is to a greater extent defined by dynamics of the ruble exchange rate than by the operation of assets holders. According to the ruble exchange rate as of 1 January 2014, the level of dollarization across all non-cash assets would have constituted barely $25 \%$ as of 1 April 2016, including 16\% for retail assets and 26\% for corporate assets. 